\title{
Exergy analysis of a solar combined cycle: organic Rankine cycle and absorption cooling system
}

\author{
Lavinia Grosu $^{1}$ - Andreea Marin ${ }^{1,2} \cdot$ Alexandru Dobrovicescu ${ }^{2} \cdot$ Diogo $_{\text {Queiros-Conde }}{ }^{1}$
}

Received: 25 November 2014/ Accepted: 27 February 2015/Published online: 19 March 2015

(C) The Author(s) 2015. This article is published with open access at Springerlink.com

\begin{abstract}
In this paper, exergy analysis is used to evaluate the performance of a combined cycle: organic Rankine cycle (ORC) and absorption cooling system (ACS) using $\mathrm{LiBr}-\mathrm{H}_{2} \mathrm{O}$, powered by a solar field with linear concentrators. The goal of this work is to design the cogeneration system able to supply electricity and ambient cooling of an academic building and to find solutions to improve the performance of the global system. Solar ACS is combined with the ORC system-its coefficient of performance depends on the inlet temperature of the generator which is imposed by the outlet of the ORC. Exergetic efficiency and exergy destruction ratio are calculated for the whole system according to the second law of thermodynamics. Exergy analysis of each sub-system leads to the choice of the optimum physical parameters for minimum local exergy destruction ratios. In this way, a different connection of the heat exchangers is proposed in order to assure a maximum heat recovery.
\end{abstract}

Keywords ORC · Organic Rankine cycle - Absorption system $\cdot \mathrm{LiBr}-\mathrm{H}_{2} \mathrm{O} \cdot$ Solar energy $\cdot$ Exergy analysis

\section{List of symbols}

A Heat exchange area $\left(\mathrm{m}^{2}\right)$

$a_{1}, a_{2}$ Thermal losses coefficient $\left(\mathrm{W} \mathrm{m}{ }^{-2} \mathrm{~K}^{-1}\right)$

Published in the Special Issue "Energy, Environment, Economics and Thermodynamics."

Lavinia Grosu

mgrosu@u-paris10.fr; lavinia.grosu@u-paris10.fr

1 University of Paris Ouest Nanterre La Défense, 50 rue Sèvres, 92410 Ville d'Avray, France

2 University of Politehnica Bucharest, 060042 Bucharest, Romania

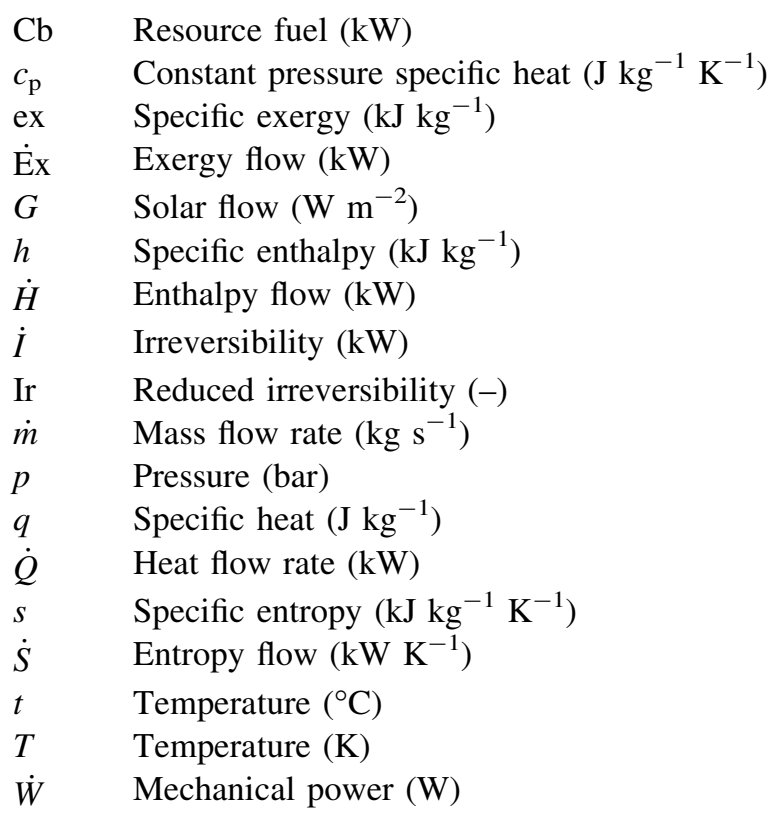

\section{Greek letters}

$\varepsilon \quad$ Relative error (\%)

$\eta \quad$ Efficiency (-)

$\sigma \quad$ Stefan-Boltzmann constant (-)

$\dot{\Pi} \quad$ Entropy generation flow $\left(\mathrm{kW} \mathrm{K}^{-1}\right)$ 


$\begin{array}{ll}\text { eff } & \text { Effective (power) } \\ \mathrm{D} & \text { Energy deficit } \\ \mathrm{i} & \text { Inlet } \\ \mathrm{g} & \text { Cooled water } \\ \mathrm{G} & \text { Generator (ACS) } \\ \mathrm{H} & \text { High (temperature/pressure) } \\ \mathrm{HE} & \text { Heat exchanger } \\ \mathrm{m} & \text { Logarithmic mean (temperature) } \\ \mathrm{ORC} & \text { Organic Rankine cycle } \\ \mathrm{o} & \text { Optical } \\ \mathrm{P} & \text { Pump } \\ \mathrm{p} & \text { Weak solution in refrigerant fluid } \\ \mathrm{r} & \text { Rich solution in refrigerant fluid } \\ \text { sol } & \text { Solar } \\ \mathrm{T} & \text { Turbine } \\ \mathrm{w} & \text { Water } \\ 0 & \text { Reference state (environment) } \\ 1-6 & \text { Thermodynamics states }\end{array}$

\begin{tabular}{ll}
\multicolumn{2}{l}{ Superscripts } \\
D & Dissipation \\
P & Product \\
R & $\begin{array}{l}\text { Resource } \\
\text { (fuel) }\end{array}$ \\
TOT & Total
\end{tabular}

\section{Introduction}

The use of renewable energy to power energetic systems leads to the diminution of the pollution and in the same time of the operation cost of the system. One of the actual concerns of the modern world is to assure the comfort in the office buildings.

In this paper, a system to supply simultaneously electricity and ambient cooling for an academic building is proposed. The main motivation to study and to install this kind of system is to reduce the annual electricity bill and to assure ambient cooling as actually cooling is assured only in a part of the building by several electrical individual systems.

Usually, these two services are assured by a local grid and an air conditioning system powered by electricity. In this work, a combined system, organic Rankine cycle (ORC) and an absorption cooling system (ACS) using $\mathrm{LiBr} / \mathrm{H}_{2} \mathrm{O}$, is studied. Both the sub-systems are connected to the same water flow heated at $140{ }^{\circ} \mathrm{C}$ on a solar field installed on the rooftop of the building. Solar field area is about $300 \mathrm{~m}^{2}$, imposed by the geometrical dimensions of the building. The goal of this study is to estimate the mechanical (electrical) power able to be supplied by an ORC and to find if the cooling of the building could be assured. The refrigerating power of the ACS is estimated about $45.6 \mathrm{~kW}$, determined by the dynamic analysis of the thermal behavior of the building.

Solar energy could be the fuel for different cooling technologies: Stirling machine [1], ejection and absorption machines [2-6]. Using thermal energy to power the absorption system offers the possibility to consider the sun as fuel for this system and ensure cooling in summer when this source is abundantly available [7].

ORC system uses an organic fluid as working fluid, which in the vapor state drives the turbine to power electricity [8]. It is a hopeful system for heat conversion to mechanical power at low temperature, adapted to solar applications. The particularity of the organic fluids is that they could be used at an evaporation temperature much lower than a conventional water turbine does, providing high efficiency [9-11]. Organic fluids used usually are: refrigerating fluid hydro-fluoro-carbon (HFC), ammonia, butane, l' iso-pentane, toluene, which have generally high molecular masses.

Several fluids were compared in previous works and it was found that R245fa provide interesting performances for a solar system ORC [12, 13]. For this fluid, the mechanical power is the higher for the same sun conditions and ambient temperature, which implies the higher thermal efficiency (for the same input energy or fuel).

The exit of the heat exchanger at the hot side of the ORC system is connected with the input of the generator of the ACS (Fig. 1). The choice of the binary solution $\left(\mathrm{LiBr} / \mathrm{H}_{2} \mathrm{O}\right)$ of this second system is based on the following states:

-high evaporation latent heat

-rectifying column or dephlegmator are not required

-not toxic, not inflammable, not explosive

-low pressure, implying low wall thickness.

The latest years, many experimental and numerical studies were conducted in order to determine absorption cooling system performances. Several scientists have studied the performances of the global system and its components for several operating points [14-16]. A simulation of a single-effect $\mathrm{H}_{2} \mathrm{O} / \mathrm{LiBr}$ absorption system for cooling and heating applications was performed by Sencan et al. [17]. Their results show that the coefficient of performance of the system increase as the heat source temperature increases, while the exergetic efficiency of the system decreases. System behavior within condenser/absorber temperature variation was studied previously by Grosu et al. [18] and the exergy analysis of the absorber pointed out the particular behavior of this component. Several tests have showed that the use of a solution heat exchanger could increase the COP by up to $60 \%$ and the solution circulation ratio had a strong effect on the system performance $[6,18,19]$. Performance analysis developed using EES has proved that the maximum exergy 


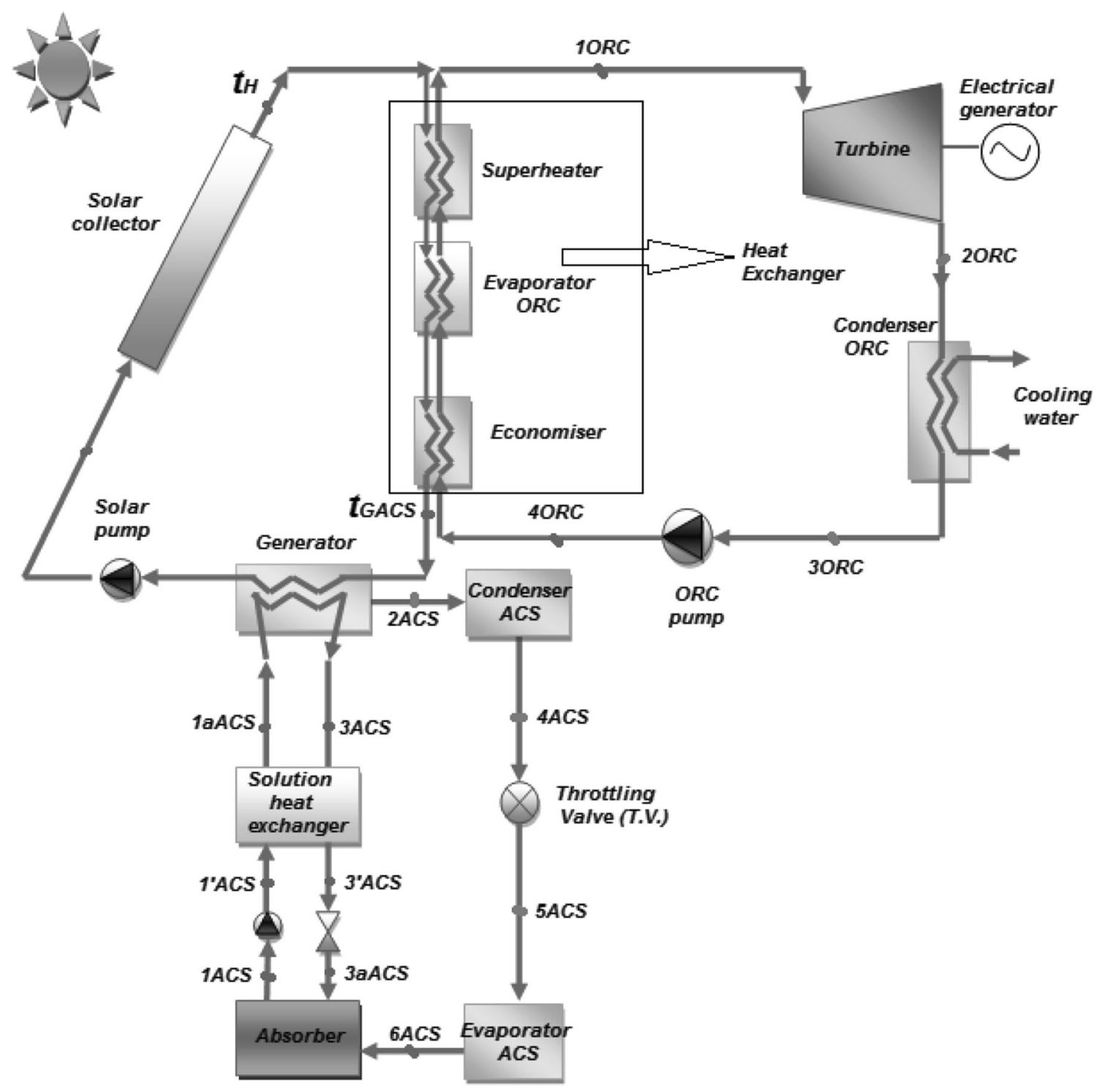

Fig. 1 Combined system ORC and ACS scheme

destruction could be noticed in the generator and the absorber $[18,20]$.

Different researchers have used exergy analysis of refrigeration systems such as Bejan [21, 22], Benelmir et al. [23], Dobrovicescu [24] and Grosu [25]. In this paper, each sub-system and the whole combined system have been analyzed using the first and the second law of the thermodynamics. A numerical model was developed to analyze the impact of several physical parameters on the performance of the system. Numerical simulation processed with EES, uses exergy approach to study the two systems and each component behavior, function of the solar field temperature. The components with high exergy losses and with important impact on the performance of the whole system are highlighted.

\section{System description}

The combined system is composed by three sub-systems: main flow (water flow within solar collectors), ORC and ACS (Fig. 1).

The organic fluid pressured by the pump is heated, then evaporated and superheated on the heat exchanger in contact with the water flow (main flow) from solar field. The superheated vapor obtained at the exit of the series of heat exchangers drives the turbine $\mathrm{ORC}$, and the mechanical power is then converted into electrical power. The vapor at the exit of the turbine is directed to the condenser where is cooled by a cooling water flow.

The solar flow then is used to heat $\mathrm{LiBr} / \mathrm{H}_{2} \mathrm{O}$ solution at the generator of the ACS. The water of this solution is thus evaporated. It constitutes the refrigerating fluid on the 
condenser, the throttling valve and the evaporator of the ACS. The cooling effect occurs in the evaporator, where chilled water is supplied at $7{ }^{\circ} \mathrm{C}$ to refresh the atmosphere of the building.

\section{Mathematics model}

\section{Organic Rankine cycle}

\section{Energy analysis}

The starting point of this study is the geometrical and thermal building analysis. It is a 10-year-old building with an available area on the rooftop about $300 \mathrm{~m}^{2}$. Wall composition, linear and surface losses, fresh air input and the occupancy scenario of building's rooms are studied to calculate the total need in conditioning which is about $45.6 \mathrm{~kW}$. The analysis of the solar collectors characteristics and the area constraint $\left(300 \mathrm{~m}^{2}\right)$ imposed by the geometrical dimensions of the building, lead to consider initial parameters of the model shown in the Table 1. The mass flow rate about $0.5 \mathrm{~kg} \mathrm{~s}^{-1}$ implies a total variation of the main flow temperature about $60{ }^{\circ} \mathrm{C}$ and a variation about $30{ }^{\circ} \mathrm{C}$ on each sub-system (ORC and ACS). All the components of the system are studied first from energetic point of view, then from exergetic point of view.

Table 1 Initial parameters of the ORC model

\begin{tabular}{|c|c|c|}
\hline Parameter & Value & Unit \\
\hline$t_{\mathrm{H}}$ & 140 & ${ }^{\circ} \mathrm{C}$ \\
\hline$\Delta t_{\mathrm{H}}=t_{\mathrm{H}}-t_{1 \mathrm{ORC}}$ & 20 & ${ }^{\circ} \mathrm{C}$ \\
\hline$\Delta t_{\mathrm{solHE}}=t_{\mathrm{H}}-t_{\mathrm{GACS}}$ & 30 & ${ }^{\circ} \mathrm{C}$ \\
\hline$\dot{m}_{\mathrm{sol}}$ & 0.5 & $\mathrm{~kg} \mathrm{~s}^{-1}$ \\
\hline$\Delta p_{\text {sol }}$ & 0.5 & bar \\
\hline$p_{\text {sol }}$ & 16 & bar \\
\hline$p_{\mathrm{HE}}$ & 10 & bar \\
\hline$\eta_{\mathrm{o}}$ & 0.64 & - \\
\hline$a_{1}$ & 0.95 & $\mathrm{~W} \mathrm{\textrm {m } ^ { - 2 }} \mathrm{K}^{-1}$ \\
\hline$a_{2}$ & 0.005 & $\mathrm{~W} \mathrm{~m} \mathrm{~m}^{-2} \mathrm{~K}^{-1}$ \\
\hline$\eta_{\mathrm{T}}$ & 85 & $\%$ \\
\hline$t_{1 \mathrm{w}}$ & 25 & ${ }^{\circ} \mathrm{C}$ \\
\hline$t_{2 \mathrm{w}}$ & 35 & ${ }^{\circ} \mathrm{C}$ \\
\hline$G$ & 800 & $\mathrm{~W} \mathrm{~m}^{-2}$ \\
\hline$t_{0}$ & 25 & ${ }^{\circ} \mathrm{C}$ \\
\hline
\end{tabular}

\section{Solar collectors}

The efficiency of the solar collectors depends on the optical efficiency $\left(\eta_{\mathrm{o}}\right)$ and the thermal losses coefficients $\left(a_{1}, a_{2}\right)$, which are given by manufacturer data and is expressed as follows:

$\eta_{\mathrm{sol}}=\eta_{\mathrm{o}}-\frac{a_{1}\left(T_{\mathrm{m}}-T_{0}\right)}{G}-\frac{a_{2}\left(T_{\mathrm{m}}-T_{0}\right)^{2}}{G}$

Heat exchanger:

$\dot{Q}_{\mathrm{HE} \_\mathrm{ORC}}=\dot{m}_{\mathrm{ORC}}\left(h_{1 \mathrm{ORC}}-h_{4 \mathrm{ORC}}\right) \quad(>0)$

Turbine:

$\dot{W}_{\mathrm{T} \_\mathrm{ORC}}=\dot{m}_{\mathrm{ORC}}\left(h_{2 \mathrm{ORC}}-h_{1 \mathrm{ORC}}\right) \quad(<0)$

Condenser:

$\dot{Q}_{\mathrm{Cd} \_\mathrm{ORC}}=\dot{m}_{\mathrm{ORC}}\left(h_{3 \mathrm{ORC}}-h_{2 \mathrm{ORC}}\right) \quad(<0)$

Pump:

$\dot{W}_{\mathrm{P} \_ \text {ORC }}=\dot{m}_{\text {ORC }}\left(h_{4 \mathrm{ORC}}-h_{3 \mathrm{ORC}}\right) \quad(>0)$

Thus, the thermal efficiency of the ORC is:

$\eta_{\mathrm{ORC}}=\frac{\left|\dot{W}_{\mathrm{T} \_\mathrm{ORC}}\right|-\dot{W}_{\mathrm{P} \_\mathrm{ORC}}}{\dot{Q}_{\mathrm{HE} \_\mathrm{ORC}}}$

Some results of the simulation are shown on Table 2, corresponding to the initial parameters from the Table 1. Mechanical power, thermal efficiency and solar field efficiency are thus determined.

\section{Exergy analysis}

Since exergy is the maximal quantity of work received or provided by a system to attain thermodynamic equilibrium with its environment by a sequence of reversible processes, exergy analysis assesses the irreversibility of each component of the system. The exergy of each sub-system is a measure of its distance from equilibrium. Thus, an exergy balance assesses the local destruction of the exergy which represents the adequate indicator to define the performance of a component or a system [21-25].

Exergy destructions at the heat exchanger, $I_{\mathrm{HE}} \mathrm{ORC}$, at the turbine, $I_{\mathrm{T} \_ \text {ORC }}$, at the condenser, $I_{\mathrm{Cd} \_ \text {ORC }}$ and at the pump $I_{\mathrm{P}_{-} \text {ORC }}$ are estimated by local exergy balances. Specific exergy as state parameter on each point of the cycle was obtained using the Thermoptim software.

Heat exchanger:
Table 2 Simulation results for $t_{\mathrm{H}}=140{ }^{\circ} \mathrm{C}$

\begin{tabular}{llllllll}
\hline $\begin{array}{l}\dot{m}_{\mathrm{ORC}} \\
\left(\mathrm{kg} \mathrm{s}^{-1}\right)\end{array}$ & $\begin{array}{l}\dot{W}_{\text {eff_ORC }} \\
(\mathrm{kW})\end{array}$ & $\begin{array}{l}\dot{Q}_{\mathrm{HE} \_\mathrm{ORC}} \\
(\mathrm{kW})\end{array}$ & $\eta_{\mathrm{ORC}}(\%)$ & $\eta_{\mathrm{sol}}(\%)$ & $A_{\mathrm{sol}}\left(\mathrm{m}^{2}\right)$ & $\begin{array}{l}\dot{m}_{\mathrm{w}} \\
\left(\mathrm{kg} \mathrm{s}^{-1}\right)\end{array}$ & $\begin{array}{l}\dot{Q}_{\mathrm{Cd} \_\mathrm{ORC}} \\
(\mathrm{kW})\end{array}$ \\
\hline 0.25 & 5.24 & 63.7 & 8.2 & 46 & 174 & 1.4 & 58.52 \\
\hline
\end{tabular}




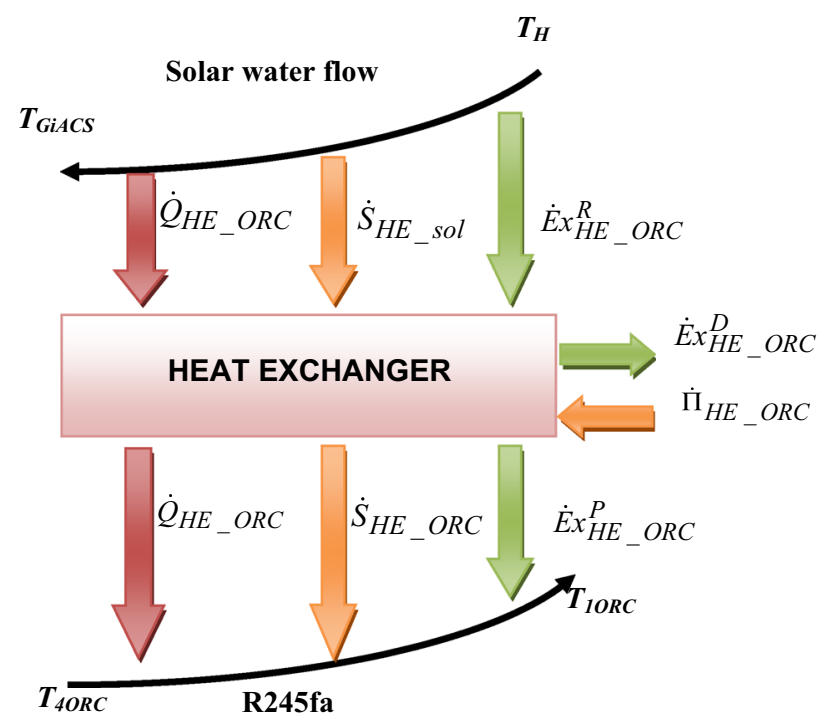

Fig. 2 Functional diagram of the heat exchanger

The heat exchanger's irreversibility may be determined using entropy balance or exergy balance which may be assessed as shown on Fig. 2.

Entropy balance:

Entropy flow received by the organic fluid may be written as following:

$\dot{S}_{\mathrm{HE} \_\mathrm{ORC}}=\dot{m}_{\mathrm{ORC}}\left(s_{1 \mathrm{ORC}}-s_{4 \mathrm{ORC}}\right) \quad(>0)$

Entropy flow supplied by the hot water from solar collectors is:

$\dot{S}_{\mathrm{HE} \_ \text {sol }}=\dot{m}_{\mathrm{sol}}\left(s_{\mathrm{GACS}}-s_{\mathrm{H}}\right) \quad(<0)$

Thus, entropy generation due to the temperature pinch on this heat exchanger is the difference of two flows above:

$\dot{\Pi}_{\mathrm{HE} \_\mathrm{ORC}}=\dot{m}_{\mathrm{ORC}}\left(s_{1 \mathrm{ORC}}-s_{4 \mathrm{ORC}}\right)-\left|\dot{m}_{\mathrm{sol}}\left(s_{\mathrm{GACS}}-s_{\mathrm{H}}\right)\right|$ $(>0)$

According to Gouy-Stodola theorem, the irreversibility associated to the heat transfer on this component is:

$\dot{I}_{\mathrm{HE} \_\mathrm{ORC}}=T_{0} \dot{\Pi}_{\mathrm{HE} \_\mathrm{ORC}} \quad(>0)$

The same equation could be obtained by an exergy approach, the heat exchanger irreversibility representing the exergy destruction during the heat transfer. A fuel, a dissipation and a product in terms of exergy will be associated to the heat.

Exergy balance:

$\dot{I}_{\mathrm{HE} \_\mathrm{ORC}}=\dot{\mathrm{Ex}} \dot{\mathrm{HE}}_{\mathrm{HE} \_\mathrm{ORC}}^{\mathrm{D}}=\dot{\mathrm{Ex}} \dot{\mathrm{H}}_{\mathrm{HE} \_\mathrm{ORC}}^{\mathrm{R}}-\dot{\mathrm{Ex}}_{\mathrm{HE} \_\mathrm{ORC}}^{\mathrm{P}}$

The fuel of the heat exchanger in terms of exergy represents the exergy flow available on the main flow:
$\dot{\mathrm{Ex}}_{\mathrm{HE} \_\mathrm{ORC}}^{\mathrm{R}}=\dot{\mathrm{Ex}} \dot{\mathrm{Q}}_{Q_{\mathrm{HE} \_\mathrm{ORC}}}^{T_{\mathrm{mH}}}=\dot{Q}_{\mathrm{HE} \_\mathrm{ORC}}\left(1-\frac{T_{0}}{T_{\mathrm{mH}}}\right)$,

where $T_{\mathrm{mH}}$ is the mean logarithmic temperature of the main flow (solar water):

$T_{\mathrm{mH}}=\frac{t_{\mathrm{H}}-t_{\mathrm{GACS}}}{\ln \left(\frac{T_{\mathrm{H}}}{T_{\mathrm{GACS}}}\right)}$.

The product of this component is the exergy flow supplied to the organic fluid:

$\dot{\mathrm{Ex}} \dot{\mathrm{P}}_{\mathrm{HE} \_\mathrm{ORC}}=\dot{m}_{\mathrm{ORC}}\left(\mathrm{ex}_{1 \mathrm{ORC}}-\mathrm{ex}_{4 \mathrm{ORC}}\right)$

The difference between fuel and product is dissipated, due to the temperature pinch between the two fluids:

$\begin{aligned} \dot{I}_{\mathrm{HE} \_\mathrm{ORC}}= & \dot{Q}_{\mathrm{HE} \_\mathrm{ORC}}\left(1-\frac{T_{0}}{T_{\mathrm{mH}}}\right)-\dot{m}_{\mathrm{ORC}}\left(\operatorname{ex}_{1 \mathrm{ORC}}\right. \\ & \left.-\mathrm{ex}_{4 \mathrm{ORC}}\right)\end{aligned}$

The exergy efficiency of the heat exchanger is the ratio of the product by the fuel:

$\eta_{\text {exHE_ORC }}=\frac{\dot{\mathrm{Ex}_{\mathrm{HE}} \mathrm{P}}}{\dot{\mathrm{Ex}}_{\mathrm{HE} \_\mathrm{ORC}}^{\mathrm{R}}}$

A reduced irreversibility may be defined in order to express the local irreversibility impact on the system fuel:

$\mathrm{Ir}_{\mathrm{HE} \_\mathrm{ORC}}=\frac{\dot{I}_{\mathrm{HE} \_\mathrm{ORC}}}{\dot{\mathrm{Ex}}_{\mathrm{HE} \_\mathrm{R} C}^{\mathrm{R}}} \times 100$

Condenser:

Following the same methods as previously, entropy and exergy flows are defined to assess the exergy efficiency of the condenser and its irreversibility impact on the fuel of the whole system (Fig. 3).

Entropy balance:

$\left|\dot{S}_{\text {Cd_ORC }}\right|=\dot{m}_{\text {ORC }}\left(s_{2 \mathrm{ORC}}-s_{3 \mathrm{ORC}}\right) \quad(>0)$

$\dot{S}_{\mathrm{Cd} \_\mathrm{w}}=\dot{m}_{\mathrm{w}}\left(s_{2 \mathrm{w}}-s_{1 \mathrm{w}}\right) \quad(>0)$

$\dot{\Pi}_{\mathrm{Cd} \_ \text {ORC }}=\dot{m}_{\mathrm{ORC}}\left(s_{2 \mathrm{ORC}}-s_{3 \mathrm{ORC}}\right)-\dot{m}_{\mathrm{w}}\left(s_{2 \mathrm{w}}-s_{1 \mathrm{w}}\right)$

$(>0)$

$\dot{I}_{\mathrm{Cd} \_\mathrm{ORC}}=T_{0} \dot{\Pi}_{\mathrm{Cd} \_\mathrm{ORC}} \quad(>0)$

Exergy balance:

$\dot{I}_{\mathrm{Cd} \_\mathrm{ORC}}=\dot{\mathrm{Ex}}_{\mathrm{Cd} \_\mathrm{ORC}}^{\mathrm{D}}=\dot{\mathrm{E}} \mathrm{x}_{\mathrm{Cd} \_\mathrm{ORC}}^{\mathrm{R}}-\dot{\mathrm{Ex}}_{\mathrm{Cd} \text { _ORC }}^{\mathrm{P}}$

$\dot{\mathrm{Ex}} \dot{\mathrm{x}}_{\mathrm{Cd} \_\mathrm{ORC}}^{\mathrm{R}}=\dot{\mathrm{E}} \mathrm{x}_{\mathrm{Q}_{\mathrm{Cd} \_\mathrm{ORC}}}^{\mathrm{T}_{\mathrm{mCd}}}=\dot{m}_{\mathrm{ORC}}\left(\mathrm{ex}_{2 \mathrm{ORC}}-\mathrm{ex}_{3 \mathrm{ORC}}\right)$

$\dot{\mathrm{Ex}}_{\mathrm{Cd} \_\mathrm{ORC}}^{\mathrm{P}}=\left|\dot{Q}_{\mathrm{Cd} \_\mathrm{ORC}}\right|\left(1-\frac{T_{0}}{T_{\mathrm{mw}}}\right)$

Thus, the irreversibility of the condenser becomes: 


$$
\begin{aligned}
\dot{I}_{\mathrm{Cd} \_\mathrm{ORC}}= & \dot{m}_{\mathrm{ORC}}\left(\mathrm{ex}_{2 \mathrm{ORC}}-\mathrm{ex}_{3 \mathrm{ORC}}\right) \\
& -\left|\dot{Q}_{\mathrm{Cd} \_\mathrm{ORC}}\right|\left(1-\frac{T_{0}}{T_{\mathrm{mw}}}\right)
\end{aligned}
$$

with

$T_{\mathrm{mw}}=\frac{t_{2 \mathrm{w}}-t_{1 \mathrm{w}}}{\ln \left(\frac{T_{2 \mathrm{w}}}{T_{1 \mathrm{w}}}\right)}$

The exergetic efficiency of the condenser is the following ratio:

$\eta_{\text {exCd_ORC }}=\frac{\dot{\mathrm{Ex}_{\mathrm{Cd}}^{\mathrm{P}}} \dot{\mathrm{Ex}}_{\mathrm{Cd} \text { ORC }}^{\mathrm{R}}}{{ }_{\mathrm{CRC}}}$

And the reduced irreversibility on the condenser is:

$\mathrm{Ir}_{\mathrm{Cd} \_\mathrm{ORC}}=\frac{\dot{I}_{\mathrm{Cd} \_\mathrm{ORC}}}{\dot{\mathrm{Ex}}_{\mathrm{HE} \_\mathrm{ORC}}^{\mathrm{R}}} \times 100$

Turbine:

The exergetic fuel on the turbine is the variation of the organic fluid-specific exergy multiplied by its mass flow rate (Fig. 4):

$\dot{\mathrm{Ex}}_{\mathrm{T} \_\mathrm{ORC}}^{\mathrm{R}}=\dot{m}_{\mathrm{ORC}}\left(\mathrm{ex}_{1 \mathrm{ORC}}-\mathrm{ex}_{2 \mathrm{ORC}}\right)$

Its product is the mechanical power to be converted into electricity:

$\dot{\mathrm{Ex}} \mathrm{x}_{\mathrm{T} \_\mathrm{ORC}}^{\mathrm{P}}=\dot{W}_{\mathrm{T} \_\mathrm{ORC}}$

The local irreversibility is:

$\dot{I}_{\mathrm{T} \_\mathrm{ORC}}=\dot{\mathrm{E}}_{\mathrm{T} \_\mathrm{ORC}}^{\mathrm{R}}-\dot{\mathrm{Ex}}_{\mathrm{T} \_\mathrm{ORC}}^{\mathrm{P}}$

The exergetic efficiency and the reduced irreversibility become as expressed here below:

$\eta_{\text {exT_ORC }}=\frac{\dot{\mathrm{Ex}_{\mathrm{T}} \mathrm{P}_{\mathrm{T}}}}{\dot{\mathrm{E}} \mathrm{x}_{\mathrm{T} \_\mathrm{ORC}}^{\mathrm{R}}}$

$\mathrm{Ir}_{\mathrm{T} \_\mathrm{ORC}}=\frac{\dot{I}_{\mathrm{T} \_\mathrm{ORC}}}{\dot{\mathrm{Ex}}_{\mathrm{HE} \_\mathrm{ORC}}^{\mathrm{R}}} \times 100$

Pump:

The pump receives the mechanical power $\dot{W}_{\text {P_ORC }}$ which represents the fuel of this component or in other terms the exergy consumed by the pump to assure a high pressure to the working fluid (Fig. 5):

$\mathrm{Ex}_{\mathrm{P} \_\mathrm{ORC}}^{\mathrm{R}}=\dot{W}_{\mathrm{P} \_\mathrm{ORC}}$

Therefore its role is to ensure a pressurized fluid at its exit, so its product is the R245fa exergy variation:

$\dot{\mathrm{Ex}}_{\mathrm{P} \_\mathrm{ORC}}^{\mathrm{P}}=\dot{m}_{\mathrm{ORC}}\left(\mathrm{ex}_{4 \mathrm{ORC}}-\mathrm{ex}_{3 \mathrm{ORC}}\right)$

Pump irreversibility is the difference between fuel and product:
$\dot{I}_{\mathrm{P} \_\mathrm{ORC}}=\dot{\mathrm{E}}_{\mathrm{P} \_\mathrm{ORC}}^{\mathrm{R}}-\dot{\mathrm{Ex}}_{\mathrm{P} \_ \text {ORC }}^{\mathrm{P}}$

As for the components above, exergy efficiency and reduced irreversibility are expressed by:

$\eta_{\text {exP_ORC }}=\frac{\dot{\dot{E x}_{\mathrm{P} \_ \text {ORC }}^{\mathrm{P}}}}{\dot{\dot{\mathrm{Ex}}_{\mathrm{P} \_ \text {ORC }}^{\mathrm{R}}}}$

$\mathrm{Ir}_{\mathrm{P} \_\mathrm{ORC}}=\frac{\dot{I}_{\mathrm{P} \_\mathrm{ORC}}}{\dot{\mathrm{Ex}}_{\mathrm{HE} \_\mathrm{ORC}}^{\mathrm{R}}}$

For the whole system, exergy efficiency takes into account the fuel of the system which corresponds to the fuel of the heat exchanger. The product is the effective mechanical power (mechanical power supplied by the turbine minus mechanical power consumed to power the pump):

$\eta_{\mathrm{exORC}}=\frac{\dot{W}_{\mathrm{T} \_\mathrm{ORC}}-\dot{W}_{\mathrm{P} \_\mathrm{ORC}}}{\dot{\mathrm{Ex}}_{\mathbf{Q H E}_{\mathrm{HE}} T_{\mathrm{ORC}}}}=\frac{\dot{W}_{\mathrm{T} \_\mathrm{ORC}}-\dot{W}_{\mathrm{P} \_\mathrm{ORC}}}{\dot{\mathrm{Ex}}_{\mathrm{HE} \_\mathrm{ORC}}^{\mathrm{R}}}$.

\section{Absorption cooling system}

\section{Energy analysis}

Initial parameters for ACS simulation, computerized with engineering equation solver (EES), are shown on Table 3.

Chilled water mass flow rate on the evaporator is calculated using cooling capacity, determined by thermal analysis of the building.

$\dot{m}_{\mathrm{wACS}}=\frac{\dot{Q}_{\mathrm{Ev} \_\mathrm{ACS}}}{c_{\mathrm{p}}\left(t_{\mathrm{EviACS}}-t_{\mathrm{EveACS}}\right)}$

Refrigerant fluid temperatures on heat exchangers of the ACS are calculated using usual temperature pinches:

$t_{\text {EvACS }}=t_{\text {EveACS }}-\Delta t_{\text {EvACS }}$

$t_{3 \mathrm{ACS}}=t_{\mathrm{GiACS}}-\Delta t_{\mathrm{GACS}}$

Pressure into the system is imposed by evaporation and condensation temperatures.

Mathematic model is built using mass, energy and exergy balances:

Evaporator:

Table 3 Initial parameters for ACS simulation

\begin{tabular}{ll}
\hline$\dot{Q}_{\text {Ev_ACS }}$ & $45.6 \mathrm{~kW}$ \\
$t_{\text {EviACS }}$ & $12{ }^{\circ} \mathrm{C}$ \\
$t_{\text {EveACS }}$ & $7{ }^{\circ} \mathrm{C}$ \\
$t_{\text {AbiACS }}=t_{\text {CdiACS }}$ & $25^{\circ} \mathrm{C}$ \\
$t_{\text {CdACS }}=t_{\text {AbACS }}$ & $36^{\circ} \mathrm{C}$ \\
$\Delta t_{\text {EvACS }}$ & $3{ }^{\circ} \mathrm{C}$ \\
$\Delta t_{\text {GACS }}$ & $3{ }^{\circ} \mathrm{C}$ \\
\hline
\end{tabular}


$q_{\text {Ev_ACS }}=h_{6 \mathrm{ACS}}-h_{5 \mathrm{ACS}}$

Thus, refrigerant (water) mass flow rate is:

$\dot{m}_{\mathrm{ef} \_\mathrm{ACS}}=\frac{\dot{Q}_{\mathrm{Ev} \_\mathrm{ACS}}}{q_{\mathrm{Ev} \_\mathrm{ACS}}}$

Condenser:

$q_{\mathrm{Cd} \_\mathrm{ACS}}=h_{2 \mathrm{ACS}}-h_{4 \mathrm{ACS}}$

$\dot{Q}_{\mathrm{Cd} \_\mathrm{ACS}}=\dot{m}_{\mathrm{ef} \_\mathrm{ACS}} q_{\mathrm{Cd} \_\mathrm{ACS}}$

Generator:

$\begin{aligned} \dot{Q}_{\mathrm{G} \_\mathrm{ACS}}= & \dot{m}_{\mathrm{ef} \_\mathrm{ACS}}\left(h_{2 \mathrm{ACS}}-h_{1 \mathrm{aACS}}\right)+\dot{m}_{\mathrm{p} \_\mathrm{ACS}}\left(h_{3 \mathrm{ACS}}\right. \\ & \left.-h_{1 \mathrm{aACS}}\right)\end{aligned}$

$q_{\mathrm{G} \_\mathrm{ACS}}=\frac{\dot{Q}_{\mathrm{G} \_\mathrm{ACS}}}{\dot{m}_{\mathrm{ef} \_\mathrm{ACS}}}$

$\dot{m}_{\mathrm{r} \_\mathrm{ACS}}=\dot{m}_{\mathrm{p} \_\mathrm{ACS}}+\dot{m}_{\mathrm{ef} \_\mathrm{ACS}}$

Absorber:

$q_{\mathrm{Ab} \_\mathrm{ACS}}=\left(h_{6 \mathrm{ACS}}-h_{1 \mathrm{ACS}}\right)+f\left(h_{3 \mathrm{aACS}}-h_{1 \mathrm{ACS}}\right)$,

where $f$ is the ratio between weak solution mass flow rate and refrigerant mass flow rate.

$\dot{Q}_{\mathrm{Ab} \_\mathrm{ACS}}=\dot{m}_{\mathrm{ef} \_\mathrm{ACS}} q_{\mathrm{Ab} \_\mathrm{ACS}}$

This energy analysis leads to generator heat flow rate, which is in this case about $70.4 \mathrm{~kW}$. Thus, the coefficient of performance of the ACS can be calculated as following:

$\mathrm{COP}_{\mathrm{ACS}}=\frac{\dot{Q}_{\mathrm{Ev} \_\mathrm{ACS}}}{\dot{Q}_{\mathrm{G} \_\mathrm{ACS}}+\dot{W}_{\mathrm{P} \_\mathrm{ACS}}}$.

\section{Exergy analysis}

Exergy analysis of the ACS is developed as for the ORC, in order to highlight local exergy destruction. Each component of the system is studied separately, by associating a fuel (exergy availability at the inlet of the component), a product (exergy produced by the component) and an exergy dissipation. The global model was studied previously [18].

Reference state is defined at $t_{0}=25^{\circ} \mathrm{C}$ and $p_{0}=101,325 \mathrm{kPa}$.

$$
\begin{aligned}
\dot{\mathrm{Ex}}_{\mathrm{G} \_\mathrm{ACS}}^{\mathrm{P}} & =\dot{\mathrm{Ex}}_{2 \mathrm{ACS}}+\dot{\mathrm{Ex}}_{3 \mathrm{ACS}} \\
& =\dot{m}_{\mathrm{ef} \_\mathrm{ACS}} \mathrm{ex}_{2 \mathrm{ACS}}+\dot{m}_{\mathrm{p} \_\mathrm{ACS}} \operatorname{ex}_{3 \mathrm{ACS}} \\
\dot{\mathrm{Ex}}_{\mathrm{G} \_\mathrm{ACS}} & =\dot{\mathrm{E}} \mathrm{x}_{1 \mathrm{aACS}}+\dot{\mathrm{E}} \mathrm{x}_{Q_{\mathrm{G}} \_\mathrm{ACS}} \\
& =\dot{m}_{\mathrm{r} \_\mathrm{ACS}} \mathrm{ex}_{1 \mathrm{aACS}}+\dot{\mathrm{E}} \mathrm{x}_{Q_{\mathrm{G} \_\mathrm{ACS}}}
\end{aligned}
$$

with

$\dot{\mathrm{Ex}}_{Q_{\mathrm{G} \_\mathrm{ACS}}}=\dot{Q}_{\mathrm{G} \_\mathrm{ACS}}\left(1-\frac{T_{0}}{T_{\mathrm{mG}}}\right)$

and

$T_{\mathrm{mG}}=\frac{t_{\mathrm{GiACS}}-t_{\mathrm{GeACS}}}{\ln \left(\frac{T_{\mathrm{GiACS}}}{T_{\mathrm{GeACS}}}\right)}$.

Exergy efficiency of the generator is the following ratio:

$\eta_{\text {exG_ACS }}=\frac{\dot{\mathrm{Ex}}_{\mathrm{G}_{\text {G_ACS }}}^{\mathrm{P}}}{\dot{\mathrm{Ex}}_{\mathrm{G} \_ \text {ACS }}^{\mathrm{R}}}$.

Its local and reduced irreversibilities are expressed here bellow:

$\dot{I}_{\mathrm{G} \_\mathrm{ACS}}=\mathrm{Cb}_{\mathrm{G} \_\mathrm{ACS}}-P_{\mathrm{G} \_\mathrm{ACS}}$

$\mathrm{Ir}_{\mathrm{G} \_\mathrm{ACS}}=\frac{\dot{I}_{\mathrm{G} \_\mathrm{ACS}}}{\dot{\mathrm{Ex}}_{\mathrm{Q}_{\mathrm{G} \_\mathrm{ACS}}}}$

After analyzing all components as shown for the generator, exergy efficiency of the ACS is calculated by the following ratio:

$\eta_{\mathrm{exACS}}=\frac{\dot{\mathrm{Ex}} \dot{\mathrm{x}}_{Q_{\mathrm{EvACS}}}^{T_{\mathrm{ev}}}}{\dot{\mathrm{Ex}}_{Q_{\mathrm{G} \_\mathrm{ACS}}}^{T_{\mathrm{mG}}}+\dot{W}_{\mathrm{P} \_\mathrm{ACS}}}$

Energy and exergy performances of the combined cycle are assessed using the expressions below:

$\eta_{\text {Global }}=\frac{\dot{Q}_{\mathrm{Ev} \_\mathrm{ACS}}+\left|\dot{W}_{\mathrm{T} \_\mathrm{ORC}}\right|-\dot{W}_{\mathrm{P} \_\mathrm{ORC}}}{\dot{Q}_{\mathrm{G} \_\mathrm{ACS}}+\dot{Q}_{\mathrm{HE} \_\mathrm{ORC}}+\dot{W}_{\mathrm{P} \_\mathrm{ACS}}}$

$\eta_{\text {exGlobal }}=\frac{\left|\dot{W}_{\mathrm{T} \_\mathrm{ORC}}\right|-\dot{W}_{\mathrm{P} \_\mathrm{ORC}}+\dot{\mathrm{Ex}}_{Q_{\mathrm{Ev} \_\mathrm{ACS}}}^{T_{\mathrm{ev}}}}{\dot{\mathrm{Ex}}_{Q_{\mathrm{G} \_\mathrm{ACS}}}^{T_{\mathrm{mG}}}+\dot{\mathrm{Ex}}_{Q_{\mathrm{HE} \_\mathrm{ORC}}}^{T_{\mathrm{mH}}}+\dot{W}_{\mathrm{P} \_\mathrm{ACS}}}$

\section{Results}

The mathematical model described in the previous section of this paper was considered to simulate the ORC behavior within temperature variation at the exit of the solar collectors $\left(t_{\mathrm{H}}\right)$ from 115 to $140{ }^{\circ} \mathrm{C}$.

Different exergy flows (fuel, product and destruction or irreversibility) are shown on Figs. 6 and 7 for two temperatures at the exit of solar collectors.

The two diagrams above lead easily and rapidly to the equation of exergy balance. In this way, results discussions are clear and lead to the choice of the optimum parameters. So, an increase in hot source temperature implies an exergy fuel $\dot{\mathrm{Ex}}_{\mathrm{HE}}^{\mathrm{R}}$ ORC (exergy availability) increase from 13.36 to $16.6 \mathrm{~kW}$. It corresponds to the maximum mechanical 


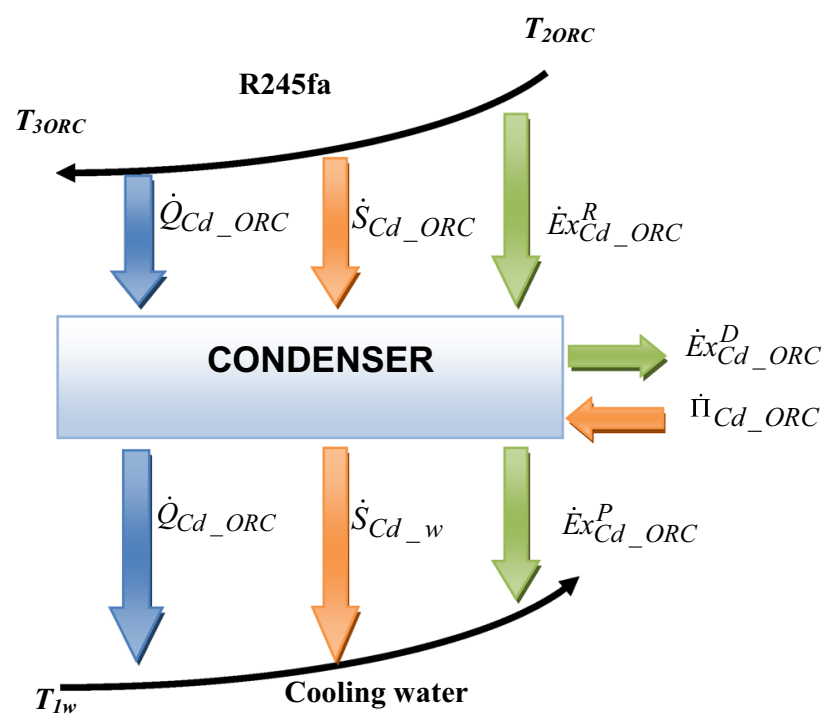

Fig. 3 Functional diagram of the condenser

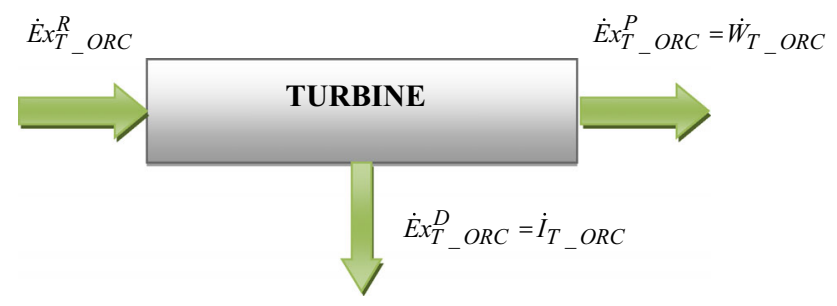

Fig. 4 Functional diagram of the turbine

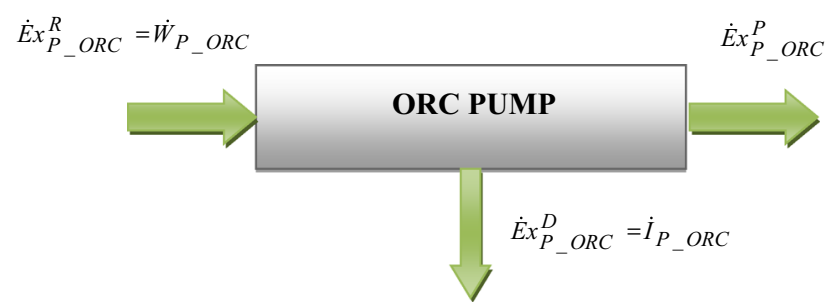

Fig. 5 Functional diagram of the pump

power which could be supplied by the system if all its components were perfect. It is therefore evident that effective mechanical power increases (from 4.67 to $5.24 \mathrm{~kW}$ ).

On the other side, the irreversibilities $\dot{I}_{\mathrm{HE} \_\mathrm{ORC}}$ and $\dot{I}_{\text {Cd_ORC increase, and consequently exergetic efficiency }}$ decreases. The same remarks could be observed on Fig. 11. For the same heat flow rate on the heat exchanger (the same temperature variation of the solar water and the same mass flow rate), both mechanical power and thermal efficiency increase. On the contrary, exergetic efficiency decreases, because of the increase of the exergy fuel (higher mean logarithmic temperature).

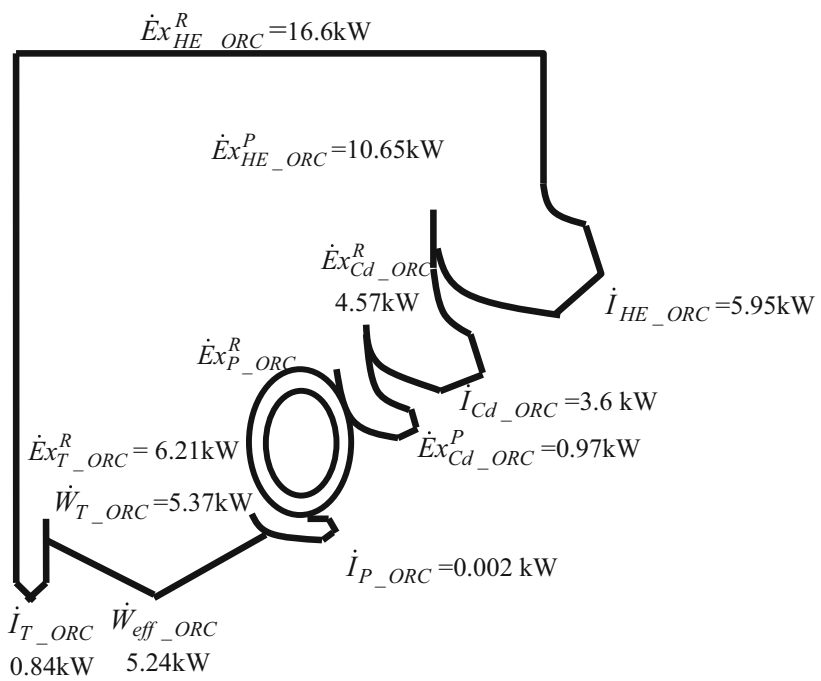

Fig. 6 ORC exergy balance scheme for $t_{\mathrm{H}}=140{ }^{\circ} \mathrm{C}$

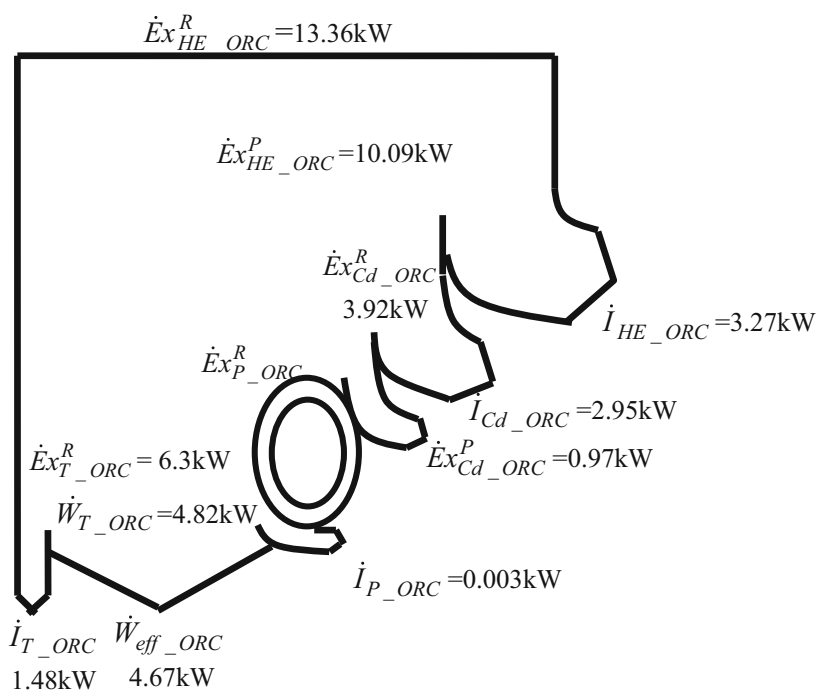

Fig. 7 ORC exergy balance scheme $t_{\mathrm{H}}=115^{\circ} \mathrm{C}$

Exergy destruction on the ORC pump is neglected, being much lower than those of the other components. Thus, Table 4 and Figs. 8 and 9 show results of only components with high irreversibility. Figures 8 and 10 show the variation, always in opposition, of local irreversibility and exergy efficiency of each component, versus exit solar collectors temperature.

The reduced irreversibility, $I_{\mathrm{r}}$, is an important indicator to take into account for the components and the whole system performance analysis. It highlights the irreversible character of each component function on the availability in terms of exergy at the beginning of the process, indicating the impact of each local irreversibility on the exergy resource (fuel) of the system.

It is interesting to remark that the reduced irreversibility on the condenser $\operatorname{Ir}_{\mathrm{Cd} \_ \text {ORC }}$ decreases slightly (Fig. 9) even 
Table 4 Values of local and reduced irreversibilities for the ORC

\begin{tabular}{lllllllc}
\hline$t_{\mathrm{H}}\left({ }^{\circ} \mathrm{C}\right)$ & $t_{\mathrm{GACS}}\left({ }^{\circ} \mathrm{C}\right)$ & $\begin{array}{l}\dot{I}_{\mathrm{Cd} \_\mathrm{ORC}} \\
(\mathrm{kW})\end{array}$ & $\begin{array}{l}\dot{I}_{\mathrm{T} \_\mathrm{ORC}} \\
(\mathrm{kW})\end{array}$ & $\begin{array}{l}\dot{I}_{\mathrm{HE} \_\mathrm{ORC}} \\
(\mathrm{kW})\end{array}$ & $\mathrm{Ir}_{\mathrm{Cd} \_\mathrm{ORC}}(\%)$ & $\mathrm{Ir}_{\mathrm{T} \_\mathrm{ORC}}(\%)$ & $\mathrm{Ir}_{\mathrm{HE} \_\mathrm{ORC}}(\%)$ \\
\hline 115 & 85 & 2.95 & 1.48 & 3.27 & 22.09 & 11.08 & 24.49 \\
120 & 90 & 3.06 & 1.36 & 3.85 & 21.83 & 9.72 & 27.44 \\
125 & 95 & 3.19 & 1.24 & 4.41 & 21.69 & 8.42 & 30.03 \\
130 & 100 & 3.31 & 1.11 & 4.95 & 21.54 & 7.25 & 32.26 \\
135 & 105 & 3.46 & 0.96 & 5.46 & 21.67 & 5.99 & 34.18 \\
140 & 110 & 3.60 & 0.83 & 5.96 & 21.71 & 5.02 & 35.88 \\
\hline
\end{tabular}
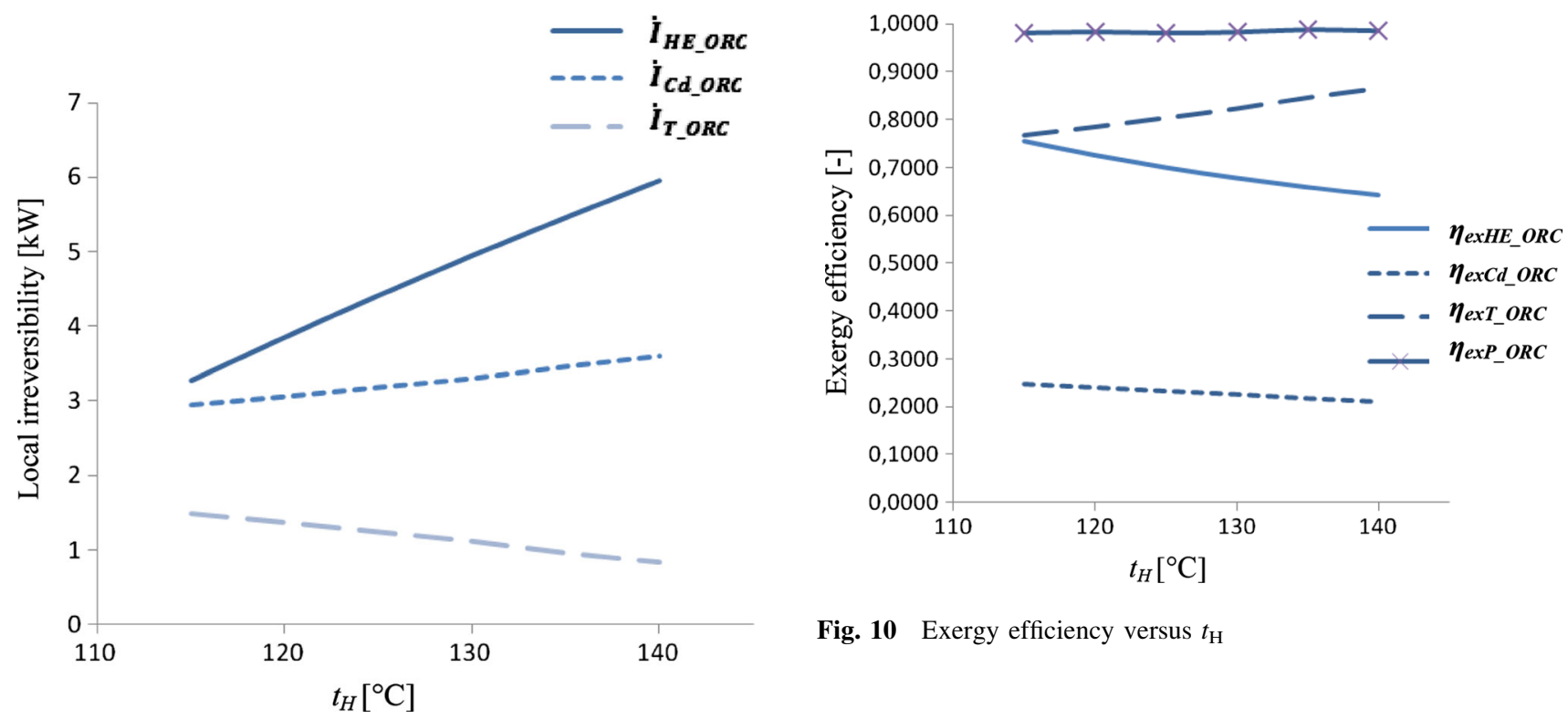

Fig. 8 Local irreversibility versus $t_{\mathrm{H}}$

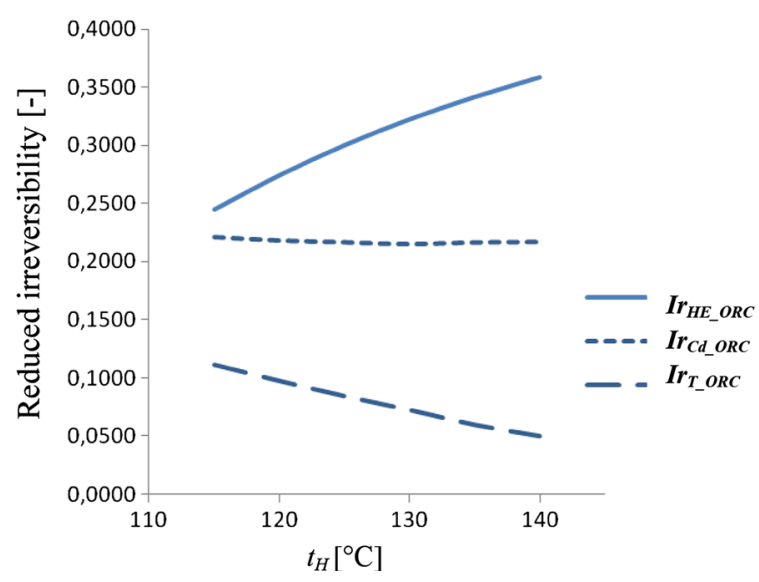

Fig. 9 Reduced irreversibility versus $t_{\mathrm{H}}$

if exergetic efficiency decrease (and local irreversibility increase, Table 4). The product of this component is constant (constant heat flow rate exchanged with cooling water), while its fuel (exergy resource) increase. Thus, the

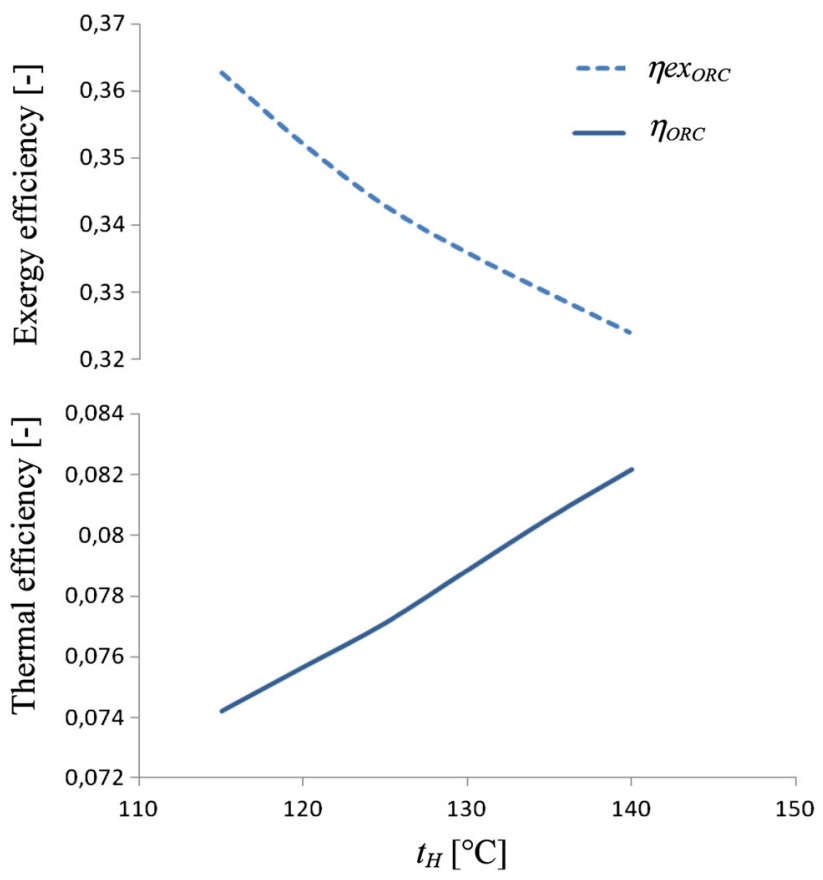

Fig. 11 Variation of $\eta_{\text {exORC }}$ and $\eta_{\mathrm{ORC}}$ versus $t_{\mathrm{H}}$ 
Table 5 Simulation results for ACS, $t_{\mathrm{H}}=140{ }^{\circ} \mathrm{C}$

\begin{tabular}{|c|c|c|c|c|c|}
\hline \multicolumn{2}{|c|}{ Energetic performances } & \multicolumn{4}{|c|}{ Exergetic performances } \\
\hline $\mathrm{COP}_{\mathrm{ACS}}$ & 0.65 & $\eta_{\text {exACS }}$ & $18.5 \%$ & $\dot{\mathrm{Ex}}_{Q_{Q_{\mathrm{G}} \_\mathrm{ACS}}^{T_{\mathrm{mG}}}}$ & $13.36 \mathrm{~kW}$ \\
\hline$\dot{m}_{\mathrm{wg}}$ & $2.18 \mathrm{~kg} \mathrm{~s}^{-1}$ & $\eta_{\mathrm{exG} \_\mathrm{ACS}}$ & $89.8 \%$ & $\dot{I}_{\mathrm{Ab} \_\mathrm{ACS}}$ & $3.44 \mathrm{~kW}$ \\
\hline$\dot{Q}_{\mathrm{Cd} \_\mathrm{ACS}}$ & $48.12 \mathrm{~kW}$ & $\eta_{\text {exHE_ACS }}$ & $63.13 \%$ & $\dot{I}_{\mathrm{Cd} \_\mathrm{ACS}}$ & $1.82 \mathrm{~kW}$ \\
\hline$\dot{Q}_{\mathrm{G} \_\mathrm{ACS}}$ & $70.41 \mathrm{~kW}$ & $\eta_{\text {exAb_ACS }}$ & $84.5 \%$ & $\dot{I}_{\mathrm{G} \_\mathrm{ACS}}$ & $3.47 \mathrm{~kW}$ \\
\hline$\dot{Q}_{\mathrm{Ab} \_\mathrm{ACS}}$ & $67.86 \mathrm{~kW}$ & $\eta_{\mathrm{exEv} \_\mathrm{ACS}}$ & $72.2 \%$ & $\dot{I}_{\mathrm{HE} \_\mathrm{ACS}}$ & $1.2 \mathrm{~kW}$ \\
\hline$\dot{m}_{\mathrm{r}}$ & $0.57 \mathrm{~kg} \mathrm{~s}^{-1}$ & $\dot{\mathrm{E}} x_{Q_{\mathrm{Ev} \_\mathrm{ACS}}}^{T_{\mathrm{mEv}}}$ & $2.48 \mathrm{~kW}$ & $\dot{I}_{\mathrm{Ev} \_\mathrm{ACS}}$ & $0.95 \mathrm{~kW}$ \\
\hline
\end{tabular}

local irreversibility increases. In the same time, the exergy flow received on the hot heat exchanger of the ORC increase, which implies a slightly decrease of the reduced irreversibility.

The ACS simulation results are shown on the Table 5 for an exit temperature of solar collectors about $140{ }^{\circ} \mathrm{C}$. Thus, the performance of the whole system can be assessed for this temperature and for solar water mass flow rate about $0.5 \mathrm{~kg} \mathrm{~s}^{-1}$ through ORC heat exchanger and ACS generator. In these conditions, a solar collector area of $300 \mathrm{~m}^{2}$ allows to provide simultaneously a mechanical power about $5.24 \mathrm{~kW}$, a cooling capacity about $45.6 \mathrm{~kW}$, with a thermal efficiency around $38 \%$ and a global exergetic efficiency around $26 \%$.

\section{Conclusion}

The goal of this work is the study of a low temperature solar combined system to provide simultaneously electricity by an ORC using R245fa as working fluid and the ambient cooling of an academic building by a $\mathrm{LiBr} / \mathrm{H}_{2} \mathrm{O}$ ACS. The main constraint of the model is the total available area on the top of the building. The combined system was studied from energetic and exergetic point of view.

The exergetic analysis allows a judicious choice of the parameters and the optimum system design. The use of a solution heat exchanger on ACS allows the increase in exergy efficiency of the ACS. The ORC components can be listed from the higher to the lower exergetic efficiency as: pump, turbine, hot heat exchanger and condenser. Thus, a way to improve the performance of this system is to add a recovery heat exchanger at the inlet of the condenser, because of its high exergy dissipation. Heat recovered could be used to preheat the working fluid before to be directed to the solar heat exchanger.

The decrease of the ORC exergetic efficiency is mainly due to the increase of the exergy resource (fuel) and of the solar heat exchanger irreversibility with the solar water temperature. The most penalizing components are hightemperature heat exchangers: the ORC solar heat exchanger, the ORC condenser, the ACS generator and the ACS absorber ACS.

The thermal storage was not studied in this paper, but is essential to ensure a constant temperature $\left(140{ }^{\circ} \mathrm{C}\right)$ at the inlet of the ORC solar heat exchanger, value for which the system is able to provide the overall ambient cooling demand of the building $(45.6 \mathrm{~kW})$.

Open Access This article is distributed under the terms of the Creative Commons Attribution License which permits any use, distribution, and reproduction in any medium, provided the original author(s) and the source are credited.

\section{References}

1. Martaj, N., Grosu, L., Rochelle, P.: Exergetical analysis and design optimization of the Stirling engine. Int. J. Exergy 3(1), 45-67 (2006)

2. Wardono, B.: Simulation of a Solar-Assisted LiBr-H2O Cooling System. Iowa State University, Ames (1994)

3. Nelson, R.M., Wardono, B.: Simulation of a solar-assisted LiBr$\mathrm{H}_{2} \mathrm{O}$ cooling system. ASHRAE Trans., 102-104 (1996)

4. Grosu, L., Feidt, M., Benelmir, R.: Study of improvement of the performance coefficient of machines operating with three reservoirs. Int. J. Exergy 1(1), 147-162 (2004)

5. Untea, A., Dobrovicescu, A., Grosu, L., Mladin, E.C.: Energy and exergy analysis of an ejector refrigeration system. UPB Sci. Bull. Ser. D Mech. Eng. 75(4), 111-126 (2013)

6. Untea, A.: Schémas hybrides de production et distribution d'énergie thermique pour bâtiments. Ph.D. Thesis, University of Paris West/University of Politehnica, Bucharest (2013)

7. Ziegler, F.: State of the art in absorption heat pumping and cooling technologies. Int. J. Refrig. 25(4), 450-459 (2002)

8. Chen, H., Goswam, D.Y., Stefanakos, E.K.: A review of thermodynamic cycle and working fluids for the conversion of lowgrade heat. Renew. Sustain. Energy Rev. 3059-3067 (2010)

9. Dai, Y., Wang, J., Gao, L.: Parametric optimization and comparative study of organic Rankine cycle (ORC) for low grade waste heat recovery. Energy Convers. Manag. 576-582 (2009)

10. Wang, X.D., Zhao, L., Wang, J.L., Zhang, W.Z., Zhao, X.Z., $\mathrm{Wu}, \mathrm{W} .:$ Performance evaluation of a low-temperature solar Rankine cycle system utilizing R245fa. Sol. Energy 84, 353-364 (2010)

11. Guo, T., Wang, H.X., Jhang, S.J.: Selection of working fluids for a novel low-temperature geothermally powered ORC based cogeneration system. Energy Convers. Manag. 946-952 (2011) 
12. Marin, A., Untea, A., Grosu, L., Dobrovicescu, A.: Parametric and exergy analysis of a combined cooling and power organic Rankine cycle. In: Microgen II: Proceedings of the 3rd edition of the International Conference on Microgeneration and Related Technologies, Italy (2013)

13. Grosu, L., Ribeiro, P., Lagouardat, A., Uhlmann, A.: Evaluation des performances et optimisation de la centrale solaire. In: Rapport de contrat MICROSOL (2014)

14. Kilic, M., Kaynakli, O.: Second law based thermodynamic analysis of water lithium bromide absorption refrigeration system. Int. J. Energy 32(8), 1505-1512 (2007)

15. Kaushik, S.C., Arora, A.: Energy and exergy analysis of single effect and series flow double effect water-lithium bromide absorption refrigeration systems. Int. J. Refrig. 33(6), 1247-1258 (2009)

16. González-Gil, A., Izquierdo, M., Marcos, J.D., Palacios, E.: Experimental evaluation of a direct aircooled lithium bromide-water absorption prototype for solar air conditioning. Appl. Therm. Eng. 31(16), 3358-3368 (2011)

17. Sencan, A., Kemal, A., Soteris, A.: Exergy analysis of lithium bromide/water absorption systems. Renew. Energy 30(5), 645-657 (2005)
18. Grosu, L., Dobrovicescu, A., Untea, A.: Energy and exergy analyses of a solar driven absorption cooling system. Int. J. Exergy 15(3), 308-327 (2014)

19. Aphornratana, S., Sriveerakul, T.: Experimental studies of a single-effect absorption refrigerator using aqueous lithium-bromide: effect of operating condition to system performance. Exp. Therm. Fluid Sci. 33(2), 658-669 (2007)

20. Zadeh, F.P., Bozorgan, N.: The energy and exergy analysis of a single effect absorption chiller. Int. J. Adv. Des. Manuf. Technol. 4(4), 19-26 (2011)

21. Bejan, A.: Entropy Generation Minimization. CRC Press, New York (1996)

22. Bejan, A., Tsatsaronis, A.G., Moran, M.: Thermal Design and Optimization. Wiley, New York (1996)

23. Benelmir, R., Grosu, L.: Exergy versus entropy analysis-illustration with a refrigerating machine. Int. J. Energy Environ. Econ. 11(1), 15-30 (2001)

24. Dobrovicescu, A.: Principiile Analizei Exergoeconomice. Politehnica Press, Bucharest (2007)

25. Grosu, L.: Exergie et systèmes énergétiques: application dans un contexte de développement durable. Rapport HDR, University of Paris West, Nanterre (2012) 